\title{
PSIKOEDUKASI SEKS MENGENAI LGBT DI SMA MUHAMMADIYAH 1 PEKANBARU
}

\author{
Ajeng Safitri*, Puti Febrina Niko, Santoso, Nur Fitriyana, Hans Erawan, \\ Baidarus \\ Prodi Psikologi Islam, Fakultas Studi Islam \\ Universitas Muhammadiyah Riau \\ email: ajengsafitri@umri.ac.id
}

\begin{abstract}
Indonesia is the 5th country with the highest number of LGBT populations in the world, namely $3 \%$ of Indonesia's 250 million population, or 3 of the 100 people who gather somewhere. LGBT behavior has a negative impact, including damage to the nerves of the brain, weakening the mind, eliminating morale and being infected with AIDS that has not been found of the medicine. The dogma of Islam strictly forbid this deviant behavior because it is not in accordance with human nature. Ironically, LGBT people are reluctant to realize that this behavior is deviant, but instead promotes their identity on social media. Even recruiting membership on social media with teenagers as the target. Therefore sex psycho-education about LGBT was done to students of Muhammadiyah 1 High School Pekanbaru with the aim of increasing students' knowledge about LGBT and being able to protect themselves and others around them from the influence of LGBT. This activity was carried out with the lectures and question and answer method. Evaluation was done at the end of the activity to see students' understanding during the activity process. Based on the results of the activity evaluation, it was generally successful and satisfying the participants. Participants hope that on other occasions they can explore more deeply the behavior of Lesbians, Gay, Bisexual and Transgender separately.
\end{abstract}

Keywords: Psychoeducation, Sex, LGBT, High School Student

\begin{abstract}
Abstrak
Indonesia menjadi negara ke-5 dengan jumlah populasi LGBT terbanyak di dunia yaitu $3 \%$ dari 250 juta penduduk Indonesia, atau 3 orang dari 100 orang yang berkumpul di suatu tempat. Perilaku LGBT mempunyai dampak negatif diantaranya rusaknya saraf otak, melemahkan akal, menghilangkan semangat kerja dan bisa terjangkit penyakit AIDS yang belum ditemukan obatnya. Ajaran Islam melarang tegas perilaku menyimpang ini karena tidak sesuai dengan fitrah manusia. Ironisnya, kaum LGBT enggan menyadari bahwa perilaku tersebut adalah menyimpang, tetapi justru marak mempromosikan identitas dirinya di media sosial. Bahkan mengadakan perekrutan keanggotaan di media sosial dengan remaja sebagai targetnya. Oleh karena itu psikoedukasi seks mengenai LGBT dilakukan kepada siswa SMA Muhammadiyah 1 Pekanbaru dengan tujuan agar menambah pengetahuan siswa tentang LGBT dan mampu melindungan diri serta orang lain di sekitarnya dari pengaruh LGBT. Kegiatan ini dilaksanakan dengan metode ceramah dan tanya jawab. Evaluasi dilakukan di akhir kegiatan untuk melihat pemahaman siswa selama proses kegiatan. Berdasarkan hasil evaluasi kegiatan, secara umum berhasil dengan baik dan memuaskan peserta. Peserta berharap di lain kesempatan dapat mengupas lebih mendalam setiap perilaku dari Lesbian, Gay, Biseksual dan Transgender secara terpisah.
\end{abstract}

Keywords: Psikoedukasi, Seks, LGBT, siswa SMA 


\section{PENDAHULUAN}

Allah menciptakan manusia sesuai fitrahnya, yaitu makhluk hidup yang berpasang-pasangan dan mengatur tentang kecenderungan orientasi seksualnya didasarkan pada pasangannya, dan mengembangkan keturunan antara suami dan istri melalui pernikahan. Ketentuan ini sesuai dengan firman Allah:

"Hai sekalian manusia, bertakwalah kepada Tuhan kamu yang telah menciptakan kamu dari diri yang satu, dan dari padanya Allah menciptakan istrinya; dan dari pada keduanya Allah mengembangkan keturunan lelaki dan wanita yang banyak. Dan bertakwalah kepada Allah yang dengan (mempergunakan) nama- Nya kamu saling meminta satu sama lain, dan (peliharalah) hubungan silaturrahim. Sesungguhnya Allah selalu menjaga dan mengawasi kamu" (QS. An-Nisa': 1).

Namun kenyataannya pada saat ini fenomena lesbian, gay, biseksual dan transgender (LGBT) menjadi isu yang banyak diperbincangkan di tengah masyarakat Indonesia. Menurut survey CIA pada tahun 2015 yang dilansir di topikmalaysia.com jumlah populasi LGBT di Indonesia adalah ke-5 terbesar di dunia setelah China, India, Eropa dan Amerika. Selain itu, beberapa lembaga survey independen dalam maupun luar negeri menyebutkan bahwa Indonesia memiliki $3 \%$ penduduk LGBT, ini berarti dari 250 juta penduduk 7,5 jutanya adalah LBGT, atau lebih sederhananya dari 100 orang yang berkumpul di suatu tempat 3 diantaranya adalah LGBT (Santoso, 2016).

Lesbian, Gay, Biseksual dan Transgender (LGBT) jika dipandang dari sudut pandang Islam merupakan masalah besar yang dampaknya sangat membahayakan bagi umat manusia. Ajaran Islam melarang tegas perilaku menyimpang ini karena tidak sesuai dengan fitrah manusia. Allah SWT berfirman:

"Mengapa kamu mendatangi jenis lelaki di antara manusia, dan kamu tinggalkan istri-istri yang dijadikan oleh Tuhanmu untukmu, bahkan kamu adalah orang-orang yang melampaui batas" (QS. Asy-Syu arâ: 165-166).

Menurut Muhammad Rashfi (Rangkuti, 2012), bahwa Islam melarang keras homoseks, karena mempunyai dampak yang negatif terhadap kehidupan pribadi dan masyarakat, antara lain: Seorang homo tidak mempunyai keinginan terhadap wanita; perasaan cinta dengan sesama jenis membawa kelainan jiwa yang menimbulkan suatu sikap dan perilaku ganjil; serta mengakibatkan rusaknya saraf otak, melemahkan akal, dan menghilangkan semangat kerja.

Di samping akibat negatif di atas, ada pula akibat yang sangat membahayakan bagi kelangsungan hidup seseorang, yakni berjangkitnya penyakit AIDS. Penyakit AIDS yang menyebar ke berbagai penjuru dunia cukup menakutkan para pelaku penyimpangan seks, karena kedokteran masih sulit menemukan obat untuk menyembuhkan penderitanya. Penderita AIDS akan kehilangan daya ketahanan tubuhnya, akibat serangan bakteri yang menggerogoti pembuluh darah, kulit, tubuh, dan alat kelamin (Rangkuti, 2012).

Ironisnya, Kaum LGBT seolah tidak menyadari dampak buruk kesehatan diri dari perilaku seks menyimpang yang dilakukannya. Mereka bahkan dengan maraknya mempromosikan atau mengiklankan identitas diri di media sosial. Propaganda perekrutan oleh kaum LGBT telah menyentuh berbagai media sosial, bahkan kelompok LGBT juga sudah menjalar ke kampus, sekolah, dan tempat umum lainnya.

Berdasarkan latar belakang ini maka penulis memilih pengabdian masyarakat 
dengan judul "Psikoedukasi Seks mengenai lesbian, gay, biseksual, dan transgender (LGBT) di SMA Muhammadiyah 1 Pekanbaru".

Tujuan dari pengabdian kepada masyarakat ini adalah untuk menciptakan pemahaman tentang Lesbian, Gay, Biseksual dan Transgender (LGBT) pada siswa SMA Muhammadiyah 1 Pekanbaru. Selain itu, dengan adanya psikoedukasi ini diharapkan para siswa mampu melindungi diri dan orang lain disekita dirinya dari pengaruh LGBT.

\section{METODE PENELITIAN}

Kegiatan pengabdian ini diawali dengan survey Tim ke lokasi pengabdian masyarakat dan berkoordinasi dengan pihak setempat. Survey yang dilakukan Tim pengabdian berupa wawancara dan observasi untuk mendapatkan gambaran umum di SMA Muhammadiyah 1 Pekanbaru.

Kegiatan pengabdian kepada masyarakat dilaksanakan dengan metode ceramah dan tanya jawab yang dilaksanakan dalam waktu 1 hari. Adapun tahapan pelaksanaan kegiatannya adalah sebagai berikut : 1) Ceramah atau penyampaian materi mengenai LGBT kepada siswa SMA Muhammadiyah 1 Pekanbaru; 2) Melakukan tanya jawab dengan siswa mengenai materi LGBT yang telah disampaikan pemateri; 3) Evaluasi akhir dilakukan untuk mengevaluasi proses yang terjadi selama kegiatan pengabdian.

Psikoedukasi seks mengenai LGBT bertujuan untuk meningkatkan pengetahuan siswa mengenai LGBT serta mampu melindungi diri dan orang lain di sekitarnya dari perilaku seks LGBT.

Psikoedukasi adalah suatu bentuk pendidikan ataupun pelatihan terhadap seseorang yang bertujuan untuk proses treatment. Sasaran dari psikoedukasi adalah untuk mengembangkan dan meningkatkan penerimaan diri serta partisipasi pasien dalam terapi dan pengembangan coping mechanism ketika pasien menghadapi hambatan yang berkaitan dengan permasalahannya (Goldman dalam Bordbar \& Faridhosseini, 2010).

Homoseksualitas adalah kesenangan yang terus menerus terjadi dengan pengalaman erotis yang melibatkan kawan sesama jenis, yang dapat atau mungkin saja tidak dapat dilakukan dengan orang lain atau dengan kata lain, homoseksualitas membuat perencanaan yang disengaja untuk memuaskan diri dan terlibat dalam fantasi atau perilaku seksual dengan sesama jenis (Dacholfany \& Khoirurrijal, 2016).

Dalam Pedoman Penggolongan dan Diagnosis Gangguan Jiwa di Indonesia III (DepKes RI, 1998), homoseksualitas dimasukkan dalam kategori gangguan psikoseksual dan disebut sebagai orientasi seksual egodistonik, yaitu "identitas jenis kelamin atau preferensi seksual tidak diragukan, tetapi individu mengharapkan yang lain disebabkan oleh gangguan psikologis dan perilaku serta mencari pengobatan untuk mengubahnya." Artinya homoseksualitas dianggap suatu kelainan hanya bila individu merasa tidak senang dengan orientasi seksualnya dan bermaksud mengubahnya.

Homoseks merupakan perbuatan keji dan termasuk dosa besar, yang merusak etika, fitrah, agama, dan jiwa manusia. Homoseks adalah hubungan biologis antara sesama jenis kelamin, baik pria maupun wanita. Namun, istilah homoseks ini kemudian lebih sering dipakai untuk seks sesama pria sedangkan yang sesama wanita dinamakan lesbian (Ibid dalam Rangkuti, 2012). Homoseks ini dilakukan dengan cara memasukkan 
zakar ke dalam dubur, sedangkan lesbian dilakukan dengan cara masturbasi satu sama lain, atau cara lainnya, untuk mencapai orgasme (climax of the sex act). Homoseks menyimpang dari fitrah manusia karena fitrah manusia cenderung kepada hubungan biologis secara heterosex, yakni hubungan seks antara pria dan wanita (Rangkuti, 2012).

Evaluasi psikoedukasi seks mengenai LGBT pada siswa SMA Muhammadiyah 1 Pekanbaru dilakukan dengan memberikan lembar evaluasi pelaksanaan kegiatan kepada siswa di akhir sesi pengabdian kepada masyarakat.

\section{HASIL DAN PEMBAHASAN}

Kegiatan pengabdian kepada masyarakat yang dilaksanakan di SMA Muhammadiyah 1 Pekanbaru. Kegiatan ini dilaksanakan sesuai dengan jadwal yang telah ditetapkan dan disepakati oleh pihak sekolah. Pengabdian kepada masyarakat ini dimulai dengan melakukan tahap persiapan, tahap ini dilakukan survey dan observasi dan permohonan izin kepada pihak SMA Muhammadiyah 1 Pekanbaru sebagai tempat pelaksanaan pengabdian ini. Selain itu pada tahap persiapan juga mencari informasi jumlah peserta dan kegiatan peserta sebelum diadakan psikoedukasi LGBT kepada siswa kelas XII SMA Muhammadiyah 1 Pekanbaru. Setelah waktu pelaksanaan disepakati, tim dari Dosen Psikologi Islam Fakultas Studi Islam menyusun jadwal pelaksanaan dan membuat kesepakan dengan pihak sekolah SMA Muhammadiyah 1 Pekanbaru.

Kegiatan ini dilaksanakan dalam rangka catur dharma Perguruan Tinggi Muhammadiyah, yang salah satu nya adalah pengabdian kepada masyarakat. Psikoedukasi ini diberikan untuk menambah pengetahuan dan wawasan para siswa tentang perilaku LGBT.
Pada tahap pelaksanaan kegiatan ini dimulai dengan tahapan persiapan, dimana tim pelaksana kegiatan melakukan briefing untuk penyiapan bahan-bahan yang dibutuhkan pada saat penyuluhan, membagi tugas masing masing instruktur, menyiapkan para peserta, menyiapkan materi psikoedukasi yang berhubungan dengan perilaku LGBT.

Tahapan pelaksanaan kegiatan dilaksanakan sesuai dengan waktu yang telah di sepakati pada tanggal 7 September 2018 bertempat di dua buah kelas sosial XII. Tahapan pelaksanaan kegiatan dimulai dengan menjelaskan materi tentang $L G B T$ dan dilanjutkan dengan sesi tanya jawab terkait materi LGBT yang diberikan. Pelaksanaan kegiatan berlangsung dari jam 9.30 11.30 WIB.

Evaluasi pada tahap pertama telah sesuai dengan indikator dan rancangan evaluasi diperoleh data sebagai berikut:

1. Jumlah peserta yang hadir sebanyak 42 orang dari 50 peserta sehingga tingkat kehadiran mencapai $84 \%$.

2. Peserta sangat terlihat antusias selama mengikuti kegiatan hingga penyuluhan selesai.

3. Setelah dilakukan psikoedukasi diharapkan para siswa dapat menambah wawasan dan pengetahuannya tentang LGBT, serta mampu melindungi diri dari pengaruh kelompok LGBT di masyarakat.

Evaluasi kegiatan secara umum berhasil dengan baik dan memuaskan peserta. Peserta berharap di lain kesempatan dapat mengupas lebih mendalam setiap perilaku dari Lesbian, Gay, Biseksual dan Transgender secara terpisah.

\section{SIMPULAN}

Secara keseluruhan kegiatan psikoedukasi seks mengenai LGBT (Lesbian, Gay, Biseks dan Transgender) 
berjalan baik dan lancar. Psikoedukasi ini memberikan pengetahuan dan wawasan baru kepada para siswa tentang seluk beluk LGBT sebagai bekal untuk melindungi diri dan orang lain dari pengaruh kelompok LGBT.

Dengan pemahaman peserta psikoedukasi tentang LGBT diharapkan akan berdampak juga pada penurunan angka kaum LGBT di Indonesia, khususnya dari kelompok pelajar SMA.

\section{UCAPAN TERIMAKASIH}

Terima kasih kami ucapkan kepada semua pihak yang mendukung kelancaran pengabdian ini terutama untuk SMA Muhammadiyah 1 Pekanbaru yang telah memberikan waktu dan kerja samanya dalam proses pengabdian kepada masyarakat. Selain itu, kepada LPPM UMRI dan Tim pengabdian Dosen yangtelah memberikan kesempatan dan kerjasama dalam terlaksananya proses pengabdian ini.

\section{DAFTAR PUSTAKA}

[1] Bordbar, M. dan Faridhosseini, F. 2010. Psychoeducation for Bipolar Mood Disorder. Jurnal: Clinical, Research, Treatment Approaches to Affective Disorders.

[2] Dacholfany, I dan Khoirurrijal. 2016. Dampak LGBT dan Antisipasinya di Masyarakat. Jurnal NIZHAM. Vo. 05, No. 01, Hal. 106119. Lampung: Universitas Muhammadiyah Metro.

[3] Departemen Kesehatan Republik Indonesia. $1998 . \quad$ Pedoman Penggolongan dan Diagnosis Gangguan Jiwa Di Indonesia, Edisi ke III.

[4] Rangkuti, R. Y. 2012. Homoseksual dalam Perspektif Hukum Islam. Asy-Syir`ah: Jurnal Ilmu Syari ah dan Hukum. Vo. 46, No. I, 191-213. Medan: Universitas Sumatera Utara.
[5] Santoso, M. B. 2016. LGBT dalam Perspektif Hal Asasi Manusia. Social Work Jurnal. Vol. 6, No. 2, Hal. 154-272. Bandung: Universitas Padjajaran. 